\title{
Cassava Mosaic Disease and Associated Gemini Viruses in Bauchi State, Nigeria: Occurrence and Distribution
}

\author{
Mustapha Abubakar, Dharmendra Singh*, Jibrin Naka Keta \\ Department of Plant Science and Biotechnology, Kebbi State University of Science and Technology, Aliero, Nigeria \\ Email address: \\ singhdharmendra12@yahoo.com (D. Singh) \\ ${ }^{*}$ Corresponding author
}

\section{To cite this article:}

Mustapha Abubakar, Dharmendra Singh, Jibrin Naka Keta. Cassava Mosaic Disease and Associated Gemini Viruses in Bauchi State, Nigeria: Occurrence and Distribution. American Journal of Plant Biology. Vol. 4, No. 4, 2019, pp. 85-90. doi: 10.11648/j.ajpb.20190404.15

Received: September 15, 2019; Accepted: September 29, 2019; Published: October 24, 2019

\begin{abstract}
Cassava mosaic disease is one of the most important biotic constraint affecting Cassava limiting the production potential of the crop in Northern Nigeria. This study was carried out to evaluate the current status of Cassava mosaic disease incidence, severity, infection type, whitefly abundance in the farmers' field as well as to determine the virus strains causing the disease in Bauchi State, North eastern Nigeria. A total of thirty three (33) farmers' fields were surveyed and in each field, thirty plants were assessed along the two diagonals with respect to disease incidence, severity, infection type and whitefly abundance and leaf samples were collected from each field for the virus diagnosis. The results revealed that Cassava mosaic disease incidence was highest in Ganjuwa (88.66\%) and lowest in Darazo (43.33\%). The disease symptom severity was generally mild. It was also highest in Ganjuwa (2.85) and lowest in Darazo (1.34). Whitefly infection is most prevalent (59.73\%) than cutting borne infection $(2.67 \%$ ) in the Districts. Adult whitefly (Bemisia tabaci) population was highest in Ganjuwa (56.33) followed by Kirfi (40.93) and lowest in Toro (27.63). Polymerase chain reaction (PCR) results using specific primers for African Cassava mosaic virus (ACMV) and East African Cassava mosaic virus (EACMV) detected single infections of ACMV and EACMV in $62.4 \%$ and $12.9 \%$ of the positive samples respectively. Co-infections of ACMV and EACMV were detected in $10.6 \%$ of the tested samples. Continuous monitoring of Cassava Mosaic Viruses and whiteflies population is required to provide appropriate management strategies of the disease in Nigeria.
\end{abstract}

Keywords: Bauchi, Severity, Whitefly, ACMV, Polymerase Chain Reaction

\section{Introduction}

Cassava (Manihot esculentus, Crantz), belonging to Euphorbiaceae family, is a perennial shrub with edible roots which grows in both tropical and subtropical areas of the world [31]. It originated from tropical America (Brazil) and was first introduced into Africa in Congo basin by Portuguese traders around $16^{\text {th }}$ Century [19]. Cassava has erect smooth stems radiating from the roots, with the stems containing nodes at intervals that give rise to new plants [28]. Leaves are large lobed, borne on a long, slender stalk joining a leaf. The colour of leaves appear dark green but in some varieties yellow or purple pigmentation may occur. Male and female flowers are found on the same plant [4].

Cassava is known to grow in different environmental conditions. It is suited to warm humid lowland tropics and it grows best in areas with mean temperature of $25-29^{\circ} \mathrm{C}$ with annual rainfall that varies between $500 \mathrm{~mm}$ and $8000 \mathrm{~mm}$ [13]. Continuous light delays storage root formation lowering yields and it is most productive when day length is up to 12 hours which falls between latitudes of $30^{\circ} \mathrm{S}$ and $30^{\circ} \mathrm{N}$. Cassava tolerates a soil $\mathrm{pH}$ range from 4 to $9[16,22]$.

The bulk of Cassava grown in Africa is utilized as food in the form of fresh roots and processed products such as flour and fermented meal preparations [17]. Furthermore, Cassava leaves are consumed as vegetables and are the source of proteins, vitamin A, B and C. They contain an average of $21 \%$ protein, which is high among non-leguminous plants [4]. The sweet Cassava varieties produced are peeled or boiled and consumed fresh. Cassava flour is used in partial substitution for wheat flour as base in canned foods, ice cream, wafers, biscuits, cakes, chips, bread and confectionary [7]. Cassava starch is used in diverse industrial applications such as baby 
formulas, pharmaceuticals, paper manufacturing, and textile industries, production of alcohol and manufacture of adhesives [4]. It is the third most important source of carbohydrate in Sub-Saharan Africa (SSA) and most important food crop in Nigeria, superseded only by rice, maize and millet in the northern part of the country. On a worldwide basis, the crop is ranked sixth most important source of calories in human diet [14]. Production of cassava varies from country to country with varying yields. In Nigeria, the average yield is around 10.6 $\mathrm{tha}^{-1}$, which is below that of Asia at $13.7 \mathrm{t} \mathrm{ha}^{-1}[12,23]$.

Cultivation of cassava in Africa and Nigeria in particular, is constrained by a number of biotic factors of which diseases are the most important [24] The diseases include cassava mosaic disease (CMD), cassava anthracnose disease (CAD), cassava bacterial blight $(\mathrm{CBB})$ and cassava brown streak disease (CBSD) [21]. CMD is caused by several distinct whitefly transmitted begomo viruses [African cassava mosaic virus (ACMV), East African cassava mosaic virus (EACMV), East African cassava mosaic Cameroon virus (EACMCV), East African cassava mosaic Uganda virus (EACMV-Ug), East African cassava mosaic Zanzibar virus (EACMZV), East African cassava mosaic Malawi virus (EACMMV), East African cassava mosaic Kenya virus (EACMKV) and South African cassava mosaic virus (SACMV) [8, 36]. Among these viruses, Cassava Mosaic Geminivirusess are the most economically important viruses of Cassava in Africa [21]. In Cassava, losses in tuber yield due to diseases can be as high as $90 \%([24,27])$. Considering the crucial role of cassava to food security and hunger alleviation in Sub-Saharan Africa, there is needed to strategize and develop ways to mitigate Cassava losses caused by diseases, particularly viruses.

This study was carried out to assess the status of Cassava mosaic disease (CMD) in Bauchi State, North eastern Nigeria. This would be of great benefit to Cassava growers, researchers especially breeders and virologists, as well as policy makers. This will also help in identifying disease hot spot areas for deployment of clean planting materials to farmers. The information will also help in guiding decisions in choosing areas suitable for Cassava seed multiplication.

\section{Methods}

\subsection{Study Area}

Nigeria's land stretches from latitude $4^{\circ} \mathrm{N}$ to $14^{\circ} \mathrm{N}$ and from longitude $3^{\circ} \mathrm{E}$ to $14^{\circ} \mathrm{E}$. Of this area, 71 million ha $(77 \%)$ are considered cultivable; about 32 million ha (45\% of the total cultivable land area) are cultivated. Annual rainfall ranges from $4000 \mathrm{~mm}$ in the coastal areas to about $500 \mathrm{~mm}$ in the far north. The temperature ranges from $26^{\circ} \mathrm{C}$ in the coastal regions to $37^{\circ} \mathrm{C}$ in the northern part [11], [2] and [37].

Bauchi state, Nigeria stretches across Sudan agro-climatic zones of the country on latitude $10^{\circ} 18^{\prime} 37.15 " \mathrm{~N}$ and longitude $9^{\circ} 50$ ' 37.97 ' $E$ with an average annual rainfall of $600 \mathrm{~mm}$ per annum. The rainy season last for only four months (June-September) in most of the regions while the rest of the year is hot and dry with temperatures ranging from $27-33^{\circ} \mathrm{C}$ in cooler period and $36-42^{\circ} \mathrm{C}$ during the hottest period [11]. The region is mostly covered by grasses and short trees and is suitable for sorghum, millet, maize, cowpea, groundnut, Cassava and cotton [33].

\subsubsection{Field Sampling and Sample Collection}

The survey was conducted in the five districts of Bauchi State, Nigeria (Toro, Alkaleri, Ganjuwa, Darazo and Kirfi). A total of 33 cassava fields (farms) aged $3-6$ months were sampled. The sampling was in farms along the major roads, secondary and feeder routes of the farmers' fields [30], [25]. In each field, 30 plants were assessed along two diagonals of the sampled field. Information about the field such as regional/location names, crop age and cultivar name were all sought from the farmers. Field coordinates were recorded using the global positioning system (GPS) [5]. Plants were assessed for CMD incidence and severity based on the type of symptoms (incidence) and degree of symptom expression (severity) as mild, severe, very severe and symptomless. Leaf samples from each severity class were collected per field and preserved in form of in herbarium specimen [10] and [28] for DNA extraction and virus diagnosis. A total of $135 \mathrm{CMD}$ symptomatic and asymptomatic leaf samples were collected and analyzed at molecular biology laboratory, Kebbi State University of Science and Technology, Aliero and Environmental Institute for Agricultural Research, Burkina Faso.

\subsubsection{CMD Incidence}

The percent disease incidence per field was calculated by expressing in percent, the total number of infected plants per total number of plants sampled using the formula of Sseruwagi et al. [33] and Mohammed et al. [24]:

$$
\text { CMD incidence }(\%)=\frac{\text { Number of plants with symptoms }}{\text { Total Number.of plants sampled }} \times 100
$$

\subsubsection{CMD Severity}

CMD severity was expressed using an arbitrary scale of 1 -5 , indicating the extent of symptom development $[15,14$, 23, 26] as follows: $1=$ Symptomless plants, $2=$ Mild chlorotic patterns affecting most of the leaves, $3=$ Pronounced chlorosis on most leaves with narrowing and distortion of lower one-third of the leaflets, $4=$ Severe Chlorosis and distortion of two-third of most of leaves and general reduction of leaf size and some stunting and $5=$ very severe (severe chlorosis, reduction of leaves, plant stunting, leaf distortion and dieback).

\subsubsection{Infection Type}

Infection types were categorized as "C" (cutting-borne) and "W" (whitefly-borne) infections. Where the lower firstformed leaves show symptoms, infection is assumed to be cutting-borne, while where only upper leaves show symptoms, infection is whitefly-borne [33].

\subsubsection{Whitefly Population}

Whitefly (Bemisia tabaci) numbers was counted on the top five fully-expanded apical leaves and the 14th leaf of the tallest shoot respectively for 5 of the 10 plants sampled per 
field and the total is recorded separately [33].

\subsection{DNA Extraction from Cassava Leaf Sample}

Total DNA was extracted from one hundred and thirty five (85) cassava leaf samples according to the protocol of [20] which was modified by [1]. Extracted DNA was resuspended in $100 \mu \mathrm{l}$ of molecular grade water and stored at $-20^{\circ} \mathrm{C}$ prior to PCR.

\subsubsection{DNA Quality Test and Quantification}

Seventy (50) out of 85 extracted DNA samples were randomly selected for DNA quality test and quantification using spectrophotometer (Nano Drop 2000C) prior to PCR running.

\subsubsection{Detection of CMD Viruses}

Cassava leaf samples were analyzed by PCR using JSP001/F (5'-ATGTCGAAGCGACCAGGAGAT-3'), JSP002/R (5'-TGTTTATTAATTGCCAATACT-3' primers for ACMV and JSP001/F and JSP003/R (5'CCTTTATTAATTTGTCACTGC-3' primers for EACMV to determine presence or absence of the virus in the field collected samples as shown in the reaction mixture below: $0.1 \mu \mathrm{Mgcl}_{2}(100 \mathrm{Mm}), 2.5 \mu \mathrm{l}$ PCR buffer (10x), $18.8 \mu \mathrm{l}$ SDW, $0.5 \mu 1$ dNTPs $(2.5 \mathrm{Mm}), 0.5 \mu 1 \mathrm{JSP} 001 / \mathrm{F}(10 \mu \mathrm{M}), 0.5$ $\mu 1 \mathrm{JSP} 002 / \mathrm{R}(10 \mu \mathrm{M}$ ACMV), $0.5 \mu \mathrm{l}$ JSP003/R $(10 \mu \mathrm{M}$ EACMV), $0.1 \mu \mathrm{l}$ of $5 \mathrm{U} / \mu \mathrm{l}$ Taq polymerase and $2.0 \mu \mathrm{l}$ of the DNA template.

The viral DNA was amplified using the standard thermal cycler, Gene Amp PCR System with the conditions below: initial denaturation at $94^{\circ} \mathrm{C}, 1$ cycle for 4 minutes, final denaturation at $94^{\circ} \mathrm{C}, 1$ cycle for 45 seconds, annealing at $52^{\circ} \mathrm{C}, 35$ cycles, 45 seconds, initial extension at $72^{\circ} \mathrm{C}, 1$ cycle 55 seconds and final extension at $72^{\circ} \mathrm{C}$, for 10 minutes.

The amplified DNA fragments were electrophoresed in $2 \%$ agarose gel stained with ethidium bromide and run at 10 volts for 30 minutes in $x 0.5$ Tris-Acetate-EDTA (TAE) buffer at $\mathrm{pH}$ 8. The gel was then visualized under UV light (transmillinator) and photographed using an Olympus digital camera with Digi Doc-gel imaging system.

\subsection{Data Analysis}

The data generated during the survey were processed and subjected to descriptive statistics using means, percentages, and standard error so as to provide summary description of the subject using descriptive statistical tools such as tables.

\section{Results}

\subsection{CMD Incidence and Severity}

Cassava mosaic disease occurred in all the five (5) Districts surveyed in Bauchi State, Nigeria with an average of $62.40 \%$. It was most prevalent in Ganjuwa $(88.66 \%)$ followed by Toro $(70 \%)$ while Darazo had the lowest disease incidence $(43.33 \%)$. Eighty percent $(80 \%)$ i.e $(4 / 5)$ of the Districts surveyed had CMD incidence greater than $50 \%$. CMD severity ranged from healthy (1.34) to very severe (2.85) with an overall mean score of 2.16. It was highest in Ganjuwa (2.85) and lowest in Darazo (1.34) (Table 1).

\subsection{CMD Infection Type}

CMD infection was categorized as Whitefly-borne and Cutting-borne infections. The percent incidence due to whitefly infection was higher $(59.73 \%)$ than cutting-borne infection $(2.67 \%)$, giving an overall average of $62.40 \%$ in the surveyed areas (Table 1). Ganjuwa had the highest whiteflyborne incidence $(85.33 \%)$, followed by Toro $(60 \%)$ with the lowest $(43.33 \%)$ recorded in Darazo. Cutting-borne infection was highest in Toro (10.0\%) than in Ganjuwa (3.33\%) and none was observed in Alkaleri, Darazo and kirfi $(0.0 \%)$ (Table 1).

\subsection{Adult Whitefly Population}

The mean number of adult whitefly in the surveyed region was generally high, which averaged 38.91 adult whiteflies per plant. Ganjuwa had the highest number of whiteflies per plant (56.33), followed by Kirfi (40.39); while Toro had 27.63 , being the lowest. The high whitefly number in most of the fields explains why vector-borne infection was generally higher in the fields assessed (Table 1).

\subsection{PCR Diagnostic Results}

From the PCR diagnosis of 85 DNA extracts analysed, 73 $(85.9 \%)$ gave positive results out of which $53(62.4 \%)$ had only ACMV, 11 (12.9\%) had only EACMV and 9 (10.6\%) had both EACMV and ACMV viruses in dual infection. ACMV was more pronounced in Alkaleri (35.2\%) followed by Ganjuwa (20.40\%) and less in Kirfi (9.4\%). EACMV was also more prevalent in Alkaleri (36.4\%) followed by Darazo (27.30\%), less in Toro and Kirfi (18.2\%) each and none in Ganjuwa (0.0\%). Alkaleri had the highest dual infections (55.6\%) while Darazo and Ganjuwa have none $(0.0 \%)$ (Table 2$)$.

Table 1. Parameters for CMD across Bauchi State, North eastern Nigeria.

\begin{tabular}{|c|c|c|c|c|c|}
\hline Districts & $\begin{array}{l}\text { Mean of whiteflies } \\
\text { number }\end{array}$ & $\begin{array}{l}\text { Mean of symptom } \\
\text { severity (1-5) }\end{array}$ & Whitefly infection (\%) & Cutting infection (\%) & Total incidence (\%) \\
\hline Toro & 27.63 & 2.75 & 60.00 & 10.00 & 70.00 \\
\hline Alkaleri & 28.54 & 2.14 & 53.33 & 0.00 & 53.33 \\
\hline Ganjuwa & 56.33 & 2.85 & 85.33 & 3.33 & 88.66 \\
\hline Darazo & 31.14 & 1.34 & 43.33 & 0.00 & 43.33 \\
\hline Kirfi & 40.93 & 1.73 & 56.67 & 0.00 & 56.67 \\
\hline Total & 194.57 & 10.8 & 298.66 & 13.33 & 311.99 \\
\hline
\end{tabular}


Table 2. Distribution of Cassava Mosaic Gemini viruses in Bauchi State, Nigeria.

\begin{tabular}{lllll}
\hline \multirow{2}{*}{ Districts } & \multirow{2}{*}{ Number of samples (\%) } & \multicolumn{4}{l}{ Cassava Mosaic Gemini viruses } & EACMV (\%) & ACMV+EACMV (\%) \\
\cline { 3 - 5 } & & ACMV (\%) & $2(18.2)$ & $3(33.3)$ \\
Toro & $16(18.8)$ & $10(18.9)$ & $4(36.4)$ & $5(55.6)$ \\
Alkaleri & $28(32.9)$ & $19(35.8)$ & $0(0.0)$ & $0(0.0)$ \\
Ganjuwa & $19(22.4)$ & $11(20.8)$ & $3(27.3)$ & $0(0.0)$ \\
Darazo & $15(17.6)$ & $8(15.1)$ & $2(18.2)$ & $1(11.1)$ \\
Kirfi & $7(8.2)$ & $5(9.4)$ & $11(12.9)$ & $9(10.6)$ \\
Total (\%) & $85(100)$ & $53(62.4)$ & & \\
\hline
\end{tabular}

\section{Discussion}

The results of this study have shown that Cassava mosaic disease (CMD) is widely distributed in all the regions of the study area giving an overall incidence of $62.4 \%$. The higher CMD incidences in Ganjuwa (88.66\%) and Toro (70\%) may be due to climatic conditions such as higher rainfall and air humidity which lead to the increase in number and activity of the Whiteflies, the vector for CMD dissemination. Similarly, susceptibility of the crop used in the study area may lead higher CMD incidences, the fact that in these areas there are only few predominant cultivars (white and red Cassava varieties), the continuous use of these cultivars could pose a threat to the crop should a more virulent virus strains or species emerged due to recombination or introduced into the area unless interventions in the form of introduction of resistant varieties and phytosanitation are practiced [19]. Whitefly-borne infections were more frequent in all the districts than cutting-borne infections. Ganjuwa had the highest whitefly incidence $(85.33 \%)$ while Darazo had the lowest (43.33\%). These results show that CMD in Bauchi State is mostly being spread by whitefly vector rather than the use of infected Cassava planting materials. It was observed from this study that disease incidence $(62.4 \%)$ is higher than was reported by [9] and [30] which reported 57.4\% and $38.4 \%$ disease incidences in Zambia in the Democratic Republic of Congo respectively but was lower than was reported by [34] with $100 \%$ incidences in Côte d'Ivoire.

PCR diagnostic results revealed that infections of African Cassava mosaic virus (ACMV) (62.4\%) were more common compared to the infections caused by East African Cassava mosaic virus (EACMV) (12.9\%). Previous studies [3] have also reported high frequency of single infections of ACMV compared to EACMV. Similarly, dual infections (ACMV+EACMV) is lower than the single infection of either ACMV or EACMV with percent incidence of $10.6 \%$. This could be due to farmers leaving out severely infected plants when selecting cuttings for planting and various campaigns and training organized for farmers and extension workers in northern Nigeria. The occurrence of dual infections in some of the districts surveyed except Darazo and Ganjuwa might be fueled by movement of infected cassava planting materials which were not tested for virus presence in the country.

Alkaleri had highest percentage of occurrence of both single and dual infections of CMD viruses which could be due to the high number of Cassava fields which may result in the accumulation of high number of whitefly vector in the state [16]. The occurrence of ACMV and EACMV in dual infected plants and single infection (EACMV) in most of the districts surveyed indicates that the prevalence of the two viruses (ACMV and EACMV) is wide spread. These findings agree with the previous studies [30] which reported the presence of the two viruses.

Severe and mild CMD symptoms severity were observed in most of areas visited. CMD severity was generally low with 2.16 as the overall mean but was highest in Ganjuwa (2.85) and lowest in Darazo (1.34). This is lower than the findings of [6] in Guinea where 2.9 was recorded as the mean severity score and what was reported by [35] with mean severity score of 3.5 on scale 1 to 5 . It was observed from this study that the districts with highest and lowest severity (Ganjuwa and Darazo) also had the highest and lowest percent incidences which indicates that there might be direct relationship between the disease severity and disease incidence. These results agreed with the previous studies [10, $30,6]$ who reported the region with the highest severity to have the highest percent disease incidence. The high severity could be due to the dual infection of ACMV and EACMV strains which highlights the fact that the more the severity the more disease incidence and virus titer as was reported by [29].

The adult whitefly population in this study which averaged 38.91 was higher than what was reported by [29] and [5] with an overall mean of 1.0 and 9.7 whiteflies per plant respectively. This may be due to differences in climatic conditions between the study areas as the climatic factors have been reported to have significant effects on the population of whitefly [16].

\section{Conclusion}

In conclusion, our study has revealed that Cassava mosaic disease is present in most of the Cassava growing areas of Bauch states, Nigeria. ACMV exists in single infection in all the districts and EACMV single infection in most of the districts except Ganjuwa. Similarly, dual infections of the two virus strains (ACMV+EACMV) has been detected in Toro, Alkaleri and Kirfi. The results also showed that CMD infection is predominantly caused by whiteflies with relatively lower cutting borne infections. Most of the states with higher whiteflies number also have the highest mean severity and percent incidence of the disease. This indicates direct relationship between whiteflies and CMD incidence, being the vector of the viruses leading to the disease. There is need thus, to make farmers well informed on the effects of 
CMD and means of getting clean planting materials. Continuous monitoring of Cassava Mosaic Disease Viruses and whiteflies population is also required to provide enough baseline data which will serve in mitigating appropriate management strategies of the disease in Nigeria.

\section{Acknowledgements}

This study was funded by Bill and Melinda Gates Foundation under PEARLS Grant OPP1112531, Wave and part of DFID Grant OPP1082413. We acknowledge farmers in surveyed areas for providing us with useful information during the study. We also appreciate Dr. Fidele and his team in INERA, Burkina Faso for the laboratory assistance.

\section{References}

[1] Abarshi, M. M., Mohammed, I. U., Jeremiah, S. C., Legg, J. P., Lava Kumar, P., Hillocks, R. J. and Maruthi, M. N. (2012). Multiplex RT-PCR assays for the simultaneous detection of both RNA and DNA viruses infecting Cassava and the common occurrence of mixed infections by two Cassava brown streak viruses in East Africa. Journal of Virology Methods. 179, 176-184.

[2] Adeniji, A. A., Ega, L. A., Akorodo, M. O., Ugwu, B. O. and Balugu, A. D. (2009). Cassava development in Nigeria. A country case study towards a Global strategy for Cassava development Pp 5-6.

[3] Alabi, O. J., Kumar, P. L. and Naidu, R. A. (2011). Cassava mosaic disease: A curse to food security in Sub Saharan Africa. Online APS net features. Retrieved 12 January 2017 from http://www.apsnet.org/publications/apsnetfeatures/Pages/cassa va.aspx

[4] Aloyce, C. R. (2013). Development and evaluation of efficient diagnostic tools for Cassava mosaic and Cassava brown streak diseases, Pp 9-15.

[5] Asare, P. A., Galyoun, I. K. A., Asare- Biediako, E., Sarfo, J. K. and Jetteh, J. P. (2014). Phenotyphic and molecular screening of Cassava Genotypes for résistance to Cassava mosaic disease. Journal of general and molecular virology. 6 (2): 6-18.

[6] Bar, E. S., Bamkefa, B. A., Winter, S. and Dixon A. G. O. (2011). Distribution and current status of Cassava mosaic disease and Begomoviruses in Guinea. Article in AJRTC. 9 (1): $17-23$.

[7] Bisimwa, E., Walangululu, J. and Bragard, C. (2012). Occurrence and Distribution of Cassava Mosaic Begomovirus Related to Agro-ecosystems in the Sud-kivu Province, Democratic Republic of Congo. Asian Journal of Plant Pathology. 6, 1-12.

[8] Bull, S. E., Briddon, R. W., Sserubombwe, W. S., Ngugi, K., Markham, P. G., and Stanley, J. (2006). Genetic diversity and phylogeography of Cassava mosaic viruses in Kenya. Journal of General Virology. 87, 3053-3065.

[9] Chikoti PC, Ndunguru J, Melis R, Tairo F, Shanahan P, and Sseruwagi $\mathrm{P}$ (2013). Cassava mosaic disease and associated viruses in Zambia: occurrence and distribution. International Journal of pest Management: 59: 63-72.
[10] Chikoti, P. C., Tembo. M., Chisola. M., Ntawarahunga. P. and Ndunguru. J. (2015). Status of Cassava mosaic disease and whitefly population in Zambia. African journal of Biotechnology. 14: 2539-2546.

[11] Douglas A, (2004). Geographical, historical and political profiles of Nigeria. Pp 6-7.

[12] Fargette, D., Konate, G., Fauquet, C. M., Muller, E., Peterschmitt, M. and Thresh, J. M. (2006). Molecular ecology and emergence of tropical plant viruses. Annals of Phytopathology: 44, 235-260.

[13] Food and Agriculture Organization of the United Nations. (2012). Food Outlook report. http://www.fao.org/docrep/014/a1981e/a1981e00.pdf

[14] Hillocks R, Maruthi M, Kulembeka H, Jeremiah S, Alacho F, Masinde E, Ogendo J, Arama P, Mulwa R, Mkamilo G, and Kimata, B. (2015). Disparity between leaf and root a root symptoms and crop losses associated withCassava brown streak disease in four countries in eastern. African Journal of phyto patholology. 64 (2): 86-93.

[15] International institute for Tropical Agriculture (IITA) (2016). Laborotory manual for the Diagnosis of Cassava Mosaic Disease, Pp 25-55.

[16] Irungu, J. (2011). Prevalence and co-infections of Cassava with Cassava mosaic Geminiviruses and and Cassava brown streak virus in popular cultivars in Western Kenya. M. Sc. dissertation. Pp 5-10.

[17] Kawano, K., 2003. Thirty years of cassava breeding for productivity-biological and social factors for success. Crop Sciences. 43: 1325-1335.

[18] Kumar, P. L., Alabi, O. J., Akinbade, S. A., Maruthi, M. N., Naidu, R. A. and Legg, J. P. (2009). Rapid single-step multiplex reverse transcription-PCR for the simultaneous detection of Cassava brown streak virus, African Cassava mosaic virus and East African Cassava mosaic virus in cassava. International Conference on Cassava Cultivation and Utilization in Central Africa Kisangani, RDC, 16 to 19th November, 2009.

[19] Kenneth, G. M. (2007). Epidemiology of Cassava mosaic disease and molecular characterization of Cassava mosaic viruses and their associated whitefly vector in South Africa, Pp 2-9.

[20] Lodhi, M. A., Ye, G. N., Weeden, N. F. and Reisch, B. (1994). A simple and efficient method for DNA extraction from grapevine cultivars and Vitis species. Plant Molecular Biology Reporter. 12: 6-13.

[21] Legg, J. P., Jeremiah, S. C., Obiero, H. M., Maruthi, M. N. Ndyetabula, I., Okao-Okuja, G., Bouwmeester, H., Bigirimana, S., Tata-Hangy, W., Gashaka, G., Mkamilo, G., Alicai, T., and Lava Kumar, P. (2011). Comparing the regional epidemiology of the Cassava mosaic and Cassava brown streak virus pandemics in Africa. Virus Research 159: 161-170.

[22] Legg, J. P., Kumar, P. L., Makeshkumar, T., Tripathi, L., Ferguson, M., Kanju, E., Ntawuruhunga, P and Cuellar, W. (2015). Cassava virus diseases: biology, epidemiolology and management. Virus Research 91: 85-142.

[23] Maruthi, M. N., Bouvaine, S., Tufan., H. A., Mohammed, I. U. and Hillocks, R. J. (2014). Transcriptional Response of virus infected Cassava and identification of putative sources of Resistance to Cassava Brown Streak Disease PLoSONE; 9 (5): e96642. doi: 10.1371/journal.pone.0096642. 
[24] Mohammed, I. U., Ghosh S, and Maruthi, M. N. (2016). Host and virus effects on reversion in Cassava affected by Cassava brown steak disease. Plant pathology. 65: 593-600.

[25] Mohammed, I. U., Ghosh, S. and Maruthi, M. N., (2017). Generating virus free Cassava by in vitro propagation with chemical and heat treatment. African journal of Biotechnology. $16,1551-1560$.

[26] Marcel, M. M., Kabwe, k., Claude, B., Patrick T, D., Stephen W., and Adrien, K. M. (2012). Incidence, severity and gravity of Cassava mosaic disease in Savannah Agro-Ecological Regions of DR- Congo: Analysis of Agro- Environmental factors. American Journal of Plant Sciences. 3: 512-519.

[27] Ndunguru, J., Fofana, B., Legg, J. P., Challappan, P., Taylor, N., Aveling, T., Thomson, G. and Fauquet, C. (2008). Two novel satellite DNAs associated with bipartite cassava mosaic begomo viruses enhanced sysmptoms and capable of breaking high virus resistance in Cassava landraces. In: Proceeding of the First Scientific Meeting of the Global Cassava Partnership (GCP-I) Ghent, Belgium, July 21-25, 2008.

[28] Ntawurahanga, P., Okao-okuja, G. Bembe, A., Obambi, M. Armand, J. C. and Legg, J. P. (2007). Incidence and diversity of Cassava mosaic disease in the Democratic Republic of Congo. African crop science journal. 15: 1-9.

[29] Obiero, H., Akhwale, M., Okao-Okuja, G. and Asiimwe, p. (2007). Monitoring and diagnostic survey of Cassava mosaic disease in Western kenya. Pp 1-13.

[30] Omongo, CA., Kawuki, R., Bellotti, A. C., Alicai, T., Baguma, Y., Maruthi, M. N., Bua, A. and Colvin, J. (2012). African Cassava Whitefly, Bemisia tabaci, Resistance in African and South American Cassava Genotypes. Journal of Integrated Agriculture. 11: 327-336.
[31] Sangare, M., Atcham, T., Olivier, K., Bagui, I., Traore, A., Jeremie, B. and Thouakesseh, Z. (2015). Classification of African mosaic virus infected Cassava leaves by the use of multi spectral imaging. Optics and phonic journals. 5: 261272.

[32] Sowunmi, A. and Akintola, J. O. (2010). Effect of climatic variability on Maize production in Nigeria. Journal of Environmental and Earths sciences. 2 (1): 19-30.

[33] Sseruwagi, P., Legg J. P., Maruthi M. N., Colvin J., Rey M. E. C. and Brown, J. K. (2009). Genetic diversity of Bemisia tabaci (Gennadius) (Hemiptera: Aleyrodidae) populations and presence of the $\mathrm{B}$ biotype and a non-B biotype that can induce silverleaf symptoms in squash in Uganda. Annual Applied Biology. 147: 253-265.

[34] Tempo, M., Mataa, M, Legg, J., and Ntawuruhunga, P. (2017) Cassava mosaic disease: incidence and yield performance of Cassava cultivers in Zambia. Journal of plant pathology. 99, 681-689.

[35] Toualy, M. N. Y., Akinbade, S., Koutoua, S., Diallo, H. and Kumar, P. L. (2014). Incidence and Distribution of Cassava mosaic begomoviruses in Côte d'Ivoire. International Journal of Agronomy and Agricultural Research, 4 (6): 131-139.

[36] Winter, S., Koerbler, M., Stein, B., Pietruszka, A., Paape, M., and Butgereitt, A. (2010). The analysis of Cassava brown streak viruses reveals the presence of distinct virus species causing Cassava brown streak disease in East Africa. Journal of General Virology. 91, 1365-1372.

[37] Worldmeters (2017). United Nations estimates. Accessed February 12, 2017. 